Hum. Hered. 1983;33:I-VI

\title{
Contents, Vol. 33, 1983
}

\section{Managing Editor}

L. Beckman, Umeå Editor

M. Hauge, Odense

Editorial Board

A.C. Allison, Harrow

A.G. Beam, New York, N.Y.

K. Berg, Oslo

J.A. Book, Uppsala

L.L. Cavalli-Sforza, Stanford, Calif.

T.J. David, Manchester

E. Essen-Möller. Lysekil

F.C. Fraser, Montreal

J.A. Fraser Roberts, London

N. Freire-Maia, Curitiba

J. Frézal, Paris

L. Gedda, Rome

R. Grubb, Lund

K. Henningsen, København

H. Lehmann, Cambridge

Margareta Mikkelsen, København

J. Mohr, København A.E. Mourant, London H. Nachtsheim, Berlin J.V. Neel, Ann Arbor, Mich.

P.O. Pedersen, København Marianne Rasmuson, Umeå S. Refsum, Oslo L.D. Sanghvi, Bombay

M. Siniscalco, Napoli E.T.O. Slater, London A.C. Stevenson, Oxford

E. Strömgren, Risskov

R. Turpin, Paris

F. Vogel, Heidelberg

M. Whittaker, Exeter

«《

S. Karger · Medical and Scientific Publishers · Basel · München · Paris · London · New York · Tokyo $\cdot$ Sydney

Drug Dosage

The authors and the publisher have exerted every effort to ensure that drug selection and dosage set forth in this text are in accord with current recommendations and practice at the time of publication. However, in view of ongoing research, changes in government regulations, and the constant flow of information relating to drug therapy and drug reactions, the reader is urged to 
check the package insert for each drug for any change in indications and dosage and for added warnings and precautions. This is particularly important when the recommended agent is a new and/or infrequently employed drug.

All rights reserved.

No part of this publication may be translated into other languages, reproduced or utilized in any form or by any means, electronic or mechanical, including photocopying, recording,

microcopying, or by any information storage and retrieval system, without permission in writing from the publisher or, in the case of photocopying, direct payment of a specified fee to the Copyright Clearance Center (see 'Information for Readers and Subscribers').

(C) Copyright 1983 by S. Karger AG,

P.O.Box, CH-4009 Basel (Switzerland) Printed in Switzerland by Buchdruckerei BaslerZeitung

+ Basler Nachrichten AG, Basel

Contents Vol. 33,1983

No. 1

Original Paper

An Exact Statistical Test for the ABO System

Haber, $\mathrm{M} \quad 1$

Gc Subtypes in Icelanders

Karlsson, S.; Skaftadóttir, I.; Árnason, A.; Thórdarson, G.; Jensson, Ó

Is There a Positive Assortative Mating for the P Blood Group?

Rasmuson, M.; Valentin, J 9

Paternity Exclusion and the Paternity Index for Two Linked Loci

Chakraborty, R; Hedrick, P.W 13

Is Pi a Selectively Balanced Polymorphism?

Martin, N.G.; Oakeshott, J.G 24

A Note on Positive Identification of Paternity by Using Genetic Markers

Majumder, P.P.; Nei, M 29

Genetic Polymorphisms of C3 and Bf in the Chinese Population

Tongmao, Z 36

The Inter- and Intra-Tribal Distribution of Red Cell G6PD Phenotypes in Sudan

Saha, N.; Samuel, A.P.W.; Omer, A.; Hoffbrand, A.V 39

Blood Groups, Haptoglobins and Red Cell Isoenzymes of the Jat Sikhs of Ludhiana District, Panjab, India

Woolley, V.; Gill, P.S.; Sunderland, E

Short Communications

Comparative Study of Phenotypes on Activity and Plasma Concentration in the Genetic System of Plasminogen

Kera, Y.; Nishimukai, H.; Yamasawa, K.; Komura, S 52

Distribution of Red Cell Enzyme Polyphorisms in South-West Poland

Dobosz, T 55

A Higher Incidence of Congenital Structural Talipes equinovarus in Gipsies

Bellyei, Á.; Czeizel, A 58

Digital Dermatoglyphics of Koyas: A Population Study

Prasad, I.D 60

Polymorphism of Delta-Aminolevulinic Acid Dehydratase in Various Populations

Benkmann, H.-G.; Bogdanski, P.; Goedde, H.W 62 
Glucose Tolerance in Patients with Cerebrovascular Accidents and Their Blood Relatives

Modi, N.M.; Srivastava, Y.; Venkatakrishna-Bhatt, H

65

Relation between Pregnancy-Associated Plasma Protein A and Fetal Sex and Blood Group

Hughes, G.; Bischof, P.; Klopper, A 69

No. 2

Original Paper

A Comparison of the Body Height of the Israeli-Born and Immigrants to Israel

Tartakovsky, M.B.; Carel, R.S.; Luz, Y

73

IV

Contents

Sero-Genetic Studies on the Caucasoids of South West Africa/Namibia

Palmhert-Keller, R.; Nurse, G.T.; Jenkins, T 79

Genetic Diversity among the Newars of Nepal

Bhasin, M.K.; Kshatriya, G.K 88

Differences in the Relative Distribution of Human Gene Diversity between Electrophoretic and

Red and

White Cell Antigen Loci

Ryman, N.; Chakraborty, R.; Nei, M 93

Estimating the Ascertainment Probability from the Number of Ascertainments per Proband

Simpson, S.P 103

The Sex Ratio of Japanese Twins

James, W.H 109

Polarity and Sex Effect in Genetic Transmission of Affective Disorders. The Single Major Locus Hypothesis

Baron, M 112

Red Cell Antigen, Plasma Protein and Red Cell Enzyme Polymorphisms in the Island of

Tasmania

Mitchell, R.J 119

Hereditary Hemoglobin Disorders in a Brazilian Population

Zago, M.A.; Costa, F.F.; Tone, L.G.; Bottura, C 125

Sex Ratio and Natural Selection at the Human ABO Locus

Millard, A.V.; Berlin, E.A 130

The Genetic Distances between the Inhabitants of Nine Mediterranean Countries and the Three

Major

Human Races

Triantaphyllidis, CD.; Kouvatsi, A.; Kaplanoglou, L 137

Alkaptonuria and Ochronosis. A Survey and 5 Cases

Christensen, K.; Manthorpe, R 140

No. 3

Original Paper

Bivariate Path Analysis of Plasma Lipids

McGue, M 145

Clinical Variability in Vitreoretinal Degeneration

Godel, V.; Regenbogen, L.; Feiler-Ofry, V.; Lazar, M

Enzyme Polymorphisms in Galicia (NW Spain) 
Carracedo, A.; Concheiro, L 160

Genetic Aspects of Myopia among the Shia Muslim Dawoodi Bohras of Udaipur, Rajsthan

Basu, S.K.; Jindal, A 163

Familial Resemblance in Catecholamine Changes to Cold Stress and Maximal Exercise

Bouchard, C; Leblanc, J.; Côté, J.; Jobin, J.; Jobin, M.; Labrie, A.; Leblanc, C 170

Short Communications

Taste Sensitivity to Phenylthiocarbamide in the Salamis Island Population (Greece)

Panayotou, T.; Kritsikis, S.; Bartsocas, C.S 179

Alphai-Antitrypsin Phenotypes in Canadian Metis

Singh, R.; Home, S.L.; Gerrard, J.W.; DeCoteau, W.E 181

Low Rates of Loss in Other Pregnancies and Liveborn Siblings of Sudden Infant Death

Syndrome Victims

Spiers, P.S 184

Group-Specific Component and Haptoglobin Phenotypes in Multiple Myeloma

Germenis, A.; Babionitakis, A.; Kaloterakis, A.; Filiotou, A.; Fertakis, A 188

Contents

$\mathrm{V}$

Haptoglobin Subtypes in Barcelona (Spain)

Moral, P.; Panadero, A.M 192

Distribution of Haptoglobin Subtypes in Continental Italy and Sardinia

Santoro, C; Olivetti, E.; Carbonara, A.0 195

Gc Subtypes in Northern Indians

Karlsson, S.; Skaftadóttir, I.; Árnason, A.; Mackintosh, P.; Jensson, Ó 199

No. 4

Original Paper

Glm(a) and Glm(x) Allotype Distribution in a Population from Calabria (Italy)

De Benedictis, G 201

Properties of the Major Gene Index and Related Functions

Mayo, O.; Eckert, S.R.; Nugroho, W.H 205

Low Haemoglobin Levels in Ai and O Blood Groups

Mukherjee, D.P.; Das, M.K 213

Human Phosphoglucomutase Locus 1: Red Cell Enzymatic Activities Associated with Common Isoelectric

Focusing Phenotypes

Scacchi, R.; Corbo, R.M.; Palmarino, R.; Sacco, G.; Arnone, M.; Lucarelli, P 218

The Cincinnati Lipid Research Clinic Family Study: Commingling in the Distributions of Lipids and

Lipoproíein Concentrations

McGue, M.; Laskarzewski, P.; Rao, D.C.; Glueck, C.J 223

Incidence of Hepatitis B (Australia) Antigen among Three Communities in Malarial Western

Maharashtra, India

Joshi, S.H.; Baxi, A.J.; Mukherjee, B.N.; Malhotra, K.C.; Kate, S.L 231

Distribution of Transferrin (Tf) Subtypes in Asian, Pacific and Australian Aboriginal

Populations:

Evidence for the Existence of a New Subtype TfC6

Kamboh, M.I.; Kirk, R.L 237 
An Exact Linkage Test for Multiple Case Families

Morton, N.E 244

Acid Phosphatase among Brahmin and Kamma Caste Populations of Coastal Andhra Pradesh, India

Naidu, J.M.; Veerraju, P 250

HLA Haplotype Segregation in Families of Type 1 Diabetics

Walsh, L.J.; Ehrlich, R.M.; Falk, J.A.; Simpson, N.E 253

Short Communication

Genetics of Plantar Interdigital Ridge Counts

Mathew, S.; Satyanarayana, M 261

No. 5

Original Paper

Association between Alpha-1-Antitrypsin Types and the Common Cold

Martin, N.G.; Oakeshott, J.G.; Clark, P.; Carr, A 265

Genetic Studies in Poland

Wolanski, N.; Nahar, R.A.; Roberts, D.F 270

Family Resemblance for Blood Pressure

Iselius, L.; Morton, N.E.; Rao, D.C 277

VI Contents

Blood Pressure Levels of Rellis (India) with Special Reference to Variations with Age

Rao, R.S 287

Extensions to Pedigree Analysis. V. Optimal Calculation of Mendelian Likelihoods

Lange, K.; Boehnke, M 291

Distribution of Hp, Tf , Gc and Pi Polymorphisms in a Nepalese Population

Yuasa, I.; Saneshige, Y.; Okamoto, N.; Ikawa, S.; Hikita, T.; Ikebuchi, J.; Inoue, T.; Okada, K 302

A Note on Fitness of Haemoglobin Genotypes in the Bengali-Speaking Population

Das, N.K.; Sarkar, J.M.; Bhattacharya, K.K.; Ghosh, A.K 307

A Genetic Study of Red Blood Cell Zinc Concentration in Man

Darlu, P.; Lalouel, J.M.; Henrotte, J.G.; Rao, D.C 311

Short Communications

Human Red Cell Glutamic-Pyruvic Transaminase Polymorphism in Serbia, Yougoslavia

Kalimanovska, V.; Majkic-Singh, N.; Stojanov, M.; Grozdanic, V.; Vucetic, G.; Andelic, ML;

Gligo-

rovic, V.; Tomasevic, $\mathrm{R} \quad 319$

Digital and Palmar Dermatoglyphic Patterns among Natives of Extreme Northwest Nepal

Larrick, J.W.; Plato, C.C 322

Normal Values for Interpupillary, Inner Canthal and Outer Canthal Distances in an Indian

Population

Singh, J.R.; Banerjee, S 326

No. 6

Original Paper

Further Studies on the Genetics of the Chamorros of Guam: Dermatoglyphics

Plato, C.C; Garruto, R.M.; Gajdusek, D.C 329

Genetic Analysis of Multiply-Affected Families of Insulin-Dependent Diabetes Mellitus (IDDM)

Probands 
Murphy, C.C; Go, R.C.P.; Acton, R.T.; Barger, B.O.; Roseman, J.M

Blood Group, Serum Protein and Red Cell Enzyme Polymorphisms in Filipinos

Windhof, O.; Walter, $\mathrm{H}$ 357

Population Studies in Northern Sweden. XL The Duffy Blood Group Polymorphism

Cedergren, B.; Nordenson, I.; Beckman, L 365

Population Studies in Northern Sweden. XII. The Haptoglobin Polymorphism

Beckman, L.; Beckman, G.; Frölander, N 371

Evaluating Pedigree Data. II. Identifying the Cause of Error in Families with Inconsistencies

Lathrop, G.M.; Huntsmann, J.W.; Hooper, A.B.; Ward, R.H

377

Short Communication

Individual Differences with Respect to the Sneezing Reflex: An Inherited Physiological Trait in Man?

Beckman, L.; Nordenson, 1 